\title{
The loss of feminine gender in Norwegian: A dialect comparison
}

\author{
Guro Busterud $^{1}$, Terje Lohndal ${ }^{1,2}$, Yulia Rodina ${ }^{2}$ and Marit Westergaard ${ }^{2,1}$ \\ 1. NTNU Norwegian University of Science and Technology, 2. UiT The Arctic \\ University of Norway
}

Corresponding author

Guro Busterud

E-mail: guro.busterud@ntnu.no

Phone: +4773596594

\begin{abstract}
It is well known that grammatical gender systems may change historically. Previous research has documented loss of the feminine gender in several Norwegian dialects, including those spoken in Oslo and Tromsø (Lødrup 2011; Rodina and Westergaard 2015a). In these dialects, the change is characterized by substitution of the feminine indefinite article $e i$ (e.g., ei bok 'a book') with the masculine form en (e.g., en bok). Child and adult native speakers of the Trondheim dialect $(N=71)$ participated in two production experiments that tested gender marking in indefinite and double definite forms, using an identical methodology to the Tromsø study. Results show that both children and adults are affected by the change. The Trondheim-Tromsø comparison reveals that the change is more advanced in the Trondheim dialect. We conclude that the loss of the feminine gender reflects a general development taking place across a number of dialects at the current time, presumably due to the high prestige of a spoken variety of one of the written standards of Norwegian.
\end{abstract}

\section{Keywords}

Grammatical gender, language acquisition, language change, semantics, morphophonology, cue, syncretism, transparency, frequency, Norwegian, Trondheim, Tromsø, dialect 


\section{Introduction}

This paper reports on an experimental study carried out in Trondheim, one of the largest cities in Norway, testing the production of grammatical gender. While Norwegian dialects traditionally have a three-gender system (masculine, feminine, neuter), a recent study of the dialect in the city of Tromsø, a city in North Norway, shows that the feminine indefinite article $e i$ 'a/an' is disappearing rapidly from the spoken language and is hardly produced any more by children, who have replaced it by the masculine form en (Rodina and Westergaard 2015a). Results from the Trondheim study show that this dialect is also affected by the current development, and moreover, that the change is even more advanced than in Tromsø, in that also teenagers and adults have substituted the feminine indefinite article by the masculine form to a large extent. Furthermore, there is no clear difference in gender marking between feminine nouns with semantic or morphophonological cues for gender assignment, suggesting that the whole class of feminine nouns is affected simultaneously. This means that the dialect is moving in the direction of a two-gender system consisting of common and neuter gender. As in Tromsø, the definite suffix typically used for feminine nouns is generally retained, although in the Trondheim data we see signs of an incipient change, as some speakers occasionally use the suffix for masculine nouns also for nouns that are typically classified as feminine. The focus in the present paper is on the change itself, not its causes, although we argue that the development is most likely due to the high prestige of a spoken version of one of the written standards Bokmål, currently affecting several urban dialects in Norway.

The paper is structured as follows. Section 2 provides relevant background information: It introduces gender in varieties of Norwegian, it presents relevant previous research, and it outlines the Tromsø study that the present paper is replicating. Our research questions are presented in section 3 , while section 4 provides information about the participants, the two experiments, and the testing procedure. The results and statistical analysis are presented in section 5, and section 6 contains a discussion of our findings.

\section{Background}

\subsection{Gender in Norwegian}

In terms of defining grammatical gender, we adopt the relatively standard approach taken by Hockett (1958: 231), which holds that "[g]enders are classes of nouns reflected in the behavior of associated words" (cf. also Corbett 1991). Importantly, this means that affixes on the noun itself, expressing e.g., number, case or definiteness, are not considered to be exponents of gender. Rather, gender is defined as agreement with the noun that is marked on other items such as determiners, adjectives, and possessives.

With this definition of gender in place, we can consider Norwegian gender systems. Norway has two written standard languages, Bokmål and Nynorsk (see Venås 1993 and Vikør 1995 for more information on the Norwegian language situation). While the number of gender categories in Norwegian has been subject to some discussion (see e.g. Vagstein 2009), it is generally assumed that Nynorsk has a three-gender system with masculine, feminine and neuter nouns, while Bokmål allows both a three- and a twogender system; in the latter case masculine and feminine have collapsed into common gender (realized by masculine forms). The majority of rural dialects have kept the threegender system (Haugen 1976: 288), whereas the picture for urban areas is less clear. Table 1 displays the traditional three-gender system rendered in Bokmål. There are 
considerable morphological differences between dialects, but Table 1 shows an idealized version of what a three-gender system typically looks like.

\begin{tabular}{|l|l|l|l|}
\hline & Masculine & Feminine & Neuter \\
\hline Indefinite & en hest a horse & ei seng a bed & et hus a house \\
\hline Definite & hesten horse.DEF & senga bed.DEF & huset house.DEF \\
\hline $\begin{array}{l}\text { Double } \\
\text { definite }\end{array}$ & $\begin{array}{l}\text { den hesten } \\
\text { that horse.DEF }\end{array}$ & $\begin{array}{l}\text { den senga } \\
\text { that bed.DEF }\end{array}$ & $\begin{array}{l}\text { det huset } \\
\text { that house.DEF }\end{array}$ \\
\hline Adjective & $\begin{array}{l}\text { en fin hest } \\
\text { a nice horse }\end{array}$ & $\begin{array}{l}\text { ei fin seng } \\
\text { a nice bed }\end{array}$ & $\begin{array}{l}\text { et fint hus } \\
\text { a nice house }\end{array}$ \\
\hline Possessive & $\begin{array}{l}\text { min hest/hesten min } \\
\text { my horse }\end{array}$ & $\begin{array}{l}\text { mi seng/senga mi } \\
\text { my bed }\end{array}$ & $\begin{array}{l}\text { mitt hus/huset mitt } \\
\text { my house }\end{array}$ \\
\hline
\end{tabular}

Table 1 . The traditional gender system in many varieties of Norwegian

As illustrated in Table 1, both the indefinite article and the possessive display a threeway gender distinction. Masculine is considered to be the default. Based on data from a corpus of eight speakers of the Tromsø dialect (Anderssen 2006; Rodina and

Westergaard 2015a) show that masculine nouns (represented by the indefinite article) is by far the most frequent one $(62.6 \%)$, whereas feminines and neuters are equally infrequent, $18.9 \%$ and $18.5 \%$ respectively. The definite article in Norwegian is a suffix, which (typically) differs across the three genders. ${ }^{1}$ There is considerable syncretism between masculine and feminine, e.g., in the adjectives. ${ }^{2}$ Norwegian also displays double definiteness, which involves marking definiteness both on a suffix on the noun itself and on a prenominal determiner. In this case, there is also syncretism between the masculine and the feminine, with den being the common form and det being the neuter. The same applies to demonstratives and certain quantifiers, not illustrated in the table: denne bilen ${ }_{M}$ 'this car', denne boka ${ }_{F}$ 'this book', and dette huset ${ }_{N}$ 'this house' for demonstratives, and all maten ${ }_{M}$ 'all the food', all suppa $F$ 'all the soup', alt rotet ${ }_{N}$ 'all the mess' for quantifiers. It should be noted that in the neuter prenominal determiner det and the suffix -et the final $t$ is silent in speech; however, in the present paper we use the written form.

The majority of Norwegians speak their dialect in all (or most) circumstances, both formal and informal, although given numerous changes currently taking place across varieties, it is not always clear what is a dialect and what is the standard (see e.g., Røyneland 2005, 2009). In fact, whether or not Norway has a standard spoken language is a heavily debated issue. The variety spoken in and around the capital, Oslo, is considered the most prestigious variety and the converge-to variety in cases of accommodation. Most changes in the language are also considered to go in the direction of this variety (see Røyneland 2005, 2009 and references therein; but see Stausland Johnsen 2015 for a different perspective). This variety is often referred to as Standard East Norwegian, a label that we use in the present paper as well. This variety is the

\footnotetext{
${ }^{1}$ There is considerable disagreement about the status of the definite suffix, and traditional Norwegian grammars (e.g., Faarlund, Lie and Vannebo 1997) consider the definite suffix to be an exponent of gender. However, we follow Hockett's definition above and consider this suffix a declension class marker, as also argued in other work, e.g., Enger (2004), Lødrup (2011), or Rodina and Westergaard (2015a).

${ }^{2}$ There is only one exception to this, the adjective 'little', i.e., liten.m, lita.F, lite., which we will not be concerned with in this paper.
} 
native spoken language for many Norwegians, and it is relatively close to the written standard Bokmål (Røyneland 2009).

Gender assignment is generally non-transparent in all varieties of Norwegian, in that there are virtually no reliable morphophonological cues. Nevertheless, Trosterud (2001) has identified as many as 43 rules for gender assignment in Norwegian, most of them with numerous exceptions. However, two rules for feminine are argued to be relatively strong cues, viz. a semantic rule for female beings (e.g., ei jente 'girl') and a morphophonological cue for nouns ending in -e, the so-called weak feminines (e.g., $e i$ bøtte 'bucket'); see Rodina and Westergaard (2015a, section 2) for more information on gender assignment.

There is generally only minor variation among dialects with respect to gender assignment: Most nouns seem to have the same gender across dialects, although this has never been studied in a comprehensive and systematic way. According to Beito (1954), some masculine and neuter nouns ending in $-e$ have migrated to the feminine gender in certain dialects (in accordance with the morphophonological cue just mentioned). This has taken place all over Norway, but is argued to occur most frequently in Nordmøre and Trøndelag, which is where Trondheim, our study area, is located (Beito 1954: 103). ${ }^{3}$ Some of these nouns are included in our study, and we therefore return to this issue below.

\subsection{Previous research}

Previous research has shown that feminine gender is vulnerable in a number of dialects in Norway - and that it is non-existent in certain varieties in the cities Bergen and Oslo (Jahr 1998, 2001; Trudgill 2013; Lødrup 2011) as well as in contact dialects such as Nordreisa and several Finnmark dialects (Conzett et al. 2011; Stabell 2016).

The Bergen dialect underwent a change centuries ago from a three-gender to a twogender system consisting of common and neuter. This means that there is no feminine indefinite article, and feminine nouns such as jente 'girl' in (2) also trigger the same inflection as a masculine noun, shown in (1). For comparison, (3) shows the form of feminine nouns in a typical three-gender dialect system.

\begin{tabular}{|c|c|}
\hline a. & en gutt \\
\hline b. & $\begin{array}{l}\text { a.COMM boy } \\
\text { gutten } \\
\text { boy.DEF }\end{array}$ \\
\hline a. & jente \\
\hline b. & $\begin{array}{l}\text { a.COMM girl } \\
\text { jenten } \\
\text { girl.DEF }\end{array}$ \\
\hline a. & ei jente \\
\hline b. & $\begin{array}{l}\text { a.F girl } \\
\text { jenta } \\
\text { girl.DEF }\end{array}$ \\
\hline
\end{tabular}

\footnotetext{
${ }^{3}$ The gender change for the neuter noun eple 'apple' is also mentioned in Hoel's (1915: 35ff) description of the local dialect in Kristiansund. According to Dalen (1990: 135) the dialect in Kristiansund is very similar to the Trondheim dialect, and finally, according to Målføresynopsen, which is a detailed overview of Norwegian dialect features, this noun is also registered as feminine in the Trondheim dialect (http://www.edd.uio.no/synops/work/hovedside.html).
} 
Scholars argue that the change in Bergen is due to extensive contact with Low German during the Hansa period (Jahr 1998, 2001; Trudgill 2013). The forms in (2a) and (2b) also correspond to what is referred to as 'educated casual style' (Torp 2005: 1428), used by the upper class in the $19^{\text {th }}$ century (Haugen 1966: 31). More recently, Lødrup (2011) shows that the feminine has been lost in many areas of Oslo, arguing that the educated casual style has spread to the traditional three-gender Oslo dialect. Lødrup's study is based on a corpus of 142 speakers, and he finds that the older speakers use very little feminine gender and the younger speakers hardly at all. Interestingly, there is a discrepancy between the indefinite determiner and the suffix, as the majority of the speakers display the pattern in (4). This means that, while the feminine gender is lost, the definite suffix has retained the declensional ending typical of feminine nouns.
a. en
jente
b. jenta
girl girl.DEF

Furthermore, there are several dialects in North Norway where Norwegian dialects have been in close contact with the Finno-Ugric languages Saami and Kven, which do not have grammatical gender. Conzett et al. (2011) have studied the villages of Kåfjord and Nordreisa, showing that the dialects spoken there have developed a two-gender system as a result of this extensive language contact. Again, the declension system is largely intact (i.e., the definite suffix), meaning that the pattern for previously feminine nouns is as shown in (4).

\subsection{The Tromso study}

The study recently conducted in Tromsø (Rodina and Westergaard 2015a) collected data from five age groups: preschoolers (Group $1, M$ age $=5 ; 2, N=15), 1^{\text {st }}$ and $2^{\text {nd }}$ graders (Group 2, $M$ age $=7 ; 6, N=12), 7^{\text {th }}$ graders (Group 3, $M$ age $=12 ; 0, N=12$ ), teenagers (Group 4, $M$ age $=18, N=17$ ) and adults (Group 5, $M$ age $=53, N=14$ ). All participants were born in Tromsø and had lived in the city most of their lives. Previous studies on bilingual children (Rodina and Westergaard 2013b, 2017) had indicated that gender in Norwegian was not in place by age 5-6, which is considerably later than in languages with transparent gender assignment. Thus, one of the goals of the study was to investigate whether the feminine gender is generally acquired late or in the process of being lost in the Tromsø dialect. All participant groups took part in two elicited production tasks.

Experiment 1 measured gender marking on indefinite articles and on prenominal determiners and suffixes in double definites (cf. Table 1). The rates for the feminine ei were very low in the child data: $15 \%, 9 \%$ and $7 \%$ in Groups 1,2 and 3 respectively. Teenagers comprised a middle group with a rate of $56 \%$. Only adults used $e i$ consistently, $99 \%$ of the time. The low rates observed in the child and teenage groups were due to overgeneralization of masculine en with feminine nouns. On the individual level, the majority of participants used only the masculine form en with the feminines (35/70). Feminine $e i$ was used exclusively by 23 out of 70 participants. Out of the remaining 12 participants who used a mixture of forms, five had a clear preference for the feminine $e i$ (one adult, three teenagers, and one child in the youngest group), while the rest had a preference for the masculine en (two teenagers and five of the youngest children). Despite the differences in the use of $e i$ across the participant groups, the use of the prenominal determiner den and the definite suffix $-a$ for the feminine was target-like 
for all groups, ranging between $98 \%$ and $100 \%$ for the determiner and between $89 \%$ and $100 \%$ for the suffix. It was thus concluded that a rapid change is taking place in the Tromsø dialect, involving loss of the feminine indefinite article, possibly also feminine gender altogether.

Experiment 2 tested speaker sensitivity to the semantic (female) and morphophonologial (the ending $-e$ ) gender cues with four subclasses of feminine nouns: nouns denoting females with a zero ending ( $e i$ heks 'a witch'), non-females ending in - $e$ ( $e$ i flaske 'a bottle'), nouns with both cues, i.e., denoting females and ending in -e ( $e i$ dame 'a lady'), and nouns with neither cue, i.e., denoting non-females and with a zero ending (ei and 'a duck'). ${ }^{4}$ Overall the results were similar to what was found in Experiment 1 . The rates for the feminine indefinite article $e i$ with feminine nouns were very low in the child data (between $10 \%$ and $21 \%$ for the four subclasses in Groups 1,2 and 3). The teenagers formed a middle group with rates varying between $63 \%$ and $71 \%$, while $100 \%$ was found only for the adults, regardless of the noun class. Semantics was found to have a weak effect in Groups 1,2,3, and 4, in that the rates for the feminine $e i$ for the two groups of nouns with female reference was significantly different from the rates for the groups with non-female reference. However, no broad conclusion could be drawn, as the study only tested six nouns in each subclass, and these could have been memorized forms. In comparison, no effect was found for the morphophonological cue.

In the Tromsø study, it was argued that the observed change is due to sociolinguistic factors (e.g., extensive dialect contact), yet its nature is due to the process of language acquisition. The nature of the change refers to the way the system changes, e.g., which properties are more vulnerable than others and therefore change faster (see e.g., Westergaard forthcoming for further discussion). Relevant factors explaining the nature of the change are syncretism (between masculine and feminine), frequency, lack of transparency, as well as early acquisition of declensional forms (bound morphemes) compared to the indefinite articles (Rodina and Westergaard 2013a). As a result, the traditional three-gender system (masculine, feminine, neuter) is replaced by a twogender system (common, neuter) in the grammars of children up to the age of approximately 12 . The simplification in the gender category is accompanied by an added complexity in the declension system, as common gender nouns now have two declensional patterns, one corresponding to the originally masculine nouns (en bilbilen 'a car' - 'the car') and the other to originally feminine nouns (en and - anda 'a duck - the duck').

\section{Research questions}

It has generally been assumed that the traditional three-gender system is quite stable in Norwegian dialects. Until Rodina and Westergaard's (2015a) study of the Tromsø dialect, loss of the feminine had not been documented outside of Bergen and Oslo or the contact dialects in North Norway (see section 2.2). The Tromsø findings have led to the question whether the loss of the feminine gender reflects a general development in Norwegian taking place at the current time, or whether this is a local Tromsø phenomenon. An indication that the loss of the feminine may be a more general trend in

\footnotetext{
${ }^{4}$ In the traditional Tromsø dialect, the weak feminines end in $-a$ instead of $-e$, e.g., ei flaska-flaska' a bottle - the bottle'. Since this feature seems to have already been lost from the speech of most age groups in Tromsø, the ending $-e$ was used in the experiment (see discussion of this in Rodina and Westergaard 2015a).
} 
many parts of Norway is found in Lohndal and Westergaard (2016), who have investigated the Nordic Dialect Corpus (Johannessen et al. 2009) and found that overall, feminine gender forms are attested 18.2\% (514/2828) among older speakers (age 50 and above) and only 5.4\% (66/1214) among younger speakers (age 30 and below). ${ }^{5} \mathrm{~A}$ recent Master thesis (Alsos 2016) has also found that there is a considerable difference between the city dialect of Tromsø and the dialect spoken in a close-by rural area (Kvaløya). Furthermore, Lundquist et al. (2016) have carried out an eyetracking study comparing the processing of gender to production data, both in Tromsø as well as a small village further south (Sortland), finding that the feminine gender forms are more stable in the village. Thus, there may be significant differences in the rate of the development, depending on factors such as the urban-rural distinction.

In order to investigate this main question, we decided to carry out the same study as was conducted in Tromsø by Rodina and Westergaard (2015a) in the city of Trondheim in the middle of Norway. Trondheim is interesting for several reasons: It is a considerably larger city than Tromsø, and it is also much closer to Oslo. Urban vernacular features have often been argued to spread from a larger city to a smaller city and yet to smaller cities again (cf. Trudgill 1974, 1983, Taeldeman 2005, Vanderkerckhove 2009 for discussion). If it is the case that the current loss of the feminine gender is the result of this kind of 'city jumping', then the Trondheim dialect should clearly also be affected by this process. In fact, we would expect the development in the Trondheim dialect to be more advanced compared to the Tromsø dialect. On the other hand, the dialect spoken in Trondheim and the surrounding area is generally considered to be quite distinct from Standard East Norwegian and might thus be expected to have retained the feminine to a larger extent. It is often claimed (in the general public discourse) that the feminine gender has an especially strong position in the Trondheim area, as several frequent nouns that are masculine in most other dialects are feminine there. One frequently mentioned example is the noun ei bil-bila' a car-the car' (Norsk ordbok, volume 2: 608; Beito 1954: 138). This and several other nouns were included in our experiment (cf. section 4.2). It is worth noticing that this phenomenon applies to the urban dialect and not the varieties spoken in the rural areas of Trondheim. ${ }^{6}$

It is important to emphasize that our main goal in this paper is not to provide a detailed explanation for the cause of any changes we may see, or to provide a complete account of differences between Trondheim and Tromsø. Rather, we are concerned with documenting the current situation, which in turn will hopefully be useful for other scholars intending to investigate the changes in more detail. Like Rodina and Westergaard (2015a), we assume that sociolinguistic factors are the most likely causes of the change. However, this is not a sociolinguistic study, and we have therefore not included any sociolinguistic variables except for age. Our study seeks to uncover the nature of the change, i.e., which properties are more vulnerable than others and thus change faster, as well as the resulting gender system in the dialect.

\footnotetext{
${ }^{5}$ It should be noted that Lohndal and Westergaard (2016) have not investigated the production of gender forms in the corpus in detail, so that these percentages could in principle be due to a coincidental low use of feminine nouns in the younger speakers.

${ }^{6}$ In the archive of Trønderordboka, the dictionary of the dialects in the Trondheim region (Seddelarkivet and "Metaordboka": http://no2014.uio.no/), bil 'car' is listed as feminine only three places in Norway: in Trondheim, Kristiansund and Surnadal. The linguist Reidar Djupedal comments that bil 'car' is feminine in Trondheim and probably in some of the closest areas. However, another note by Johan Aspjell suggests that this form did not spread outside of Trondheim.
} 
In addition to the main research question, we also want to investigate whether the rate of the development is similar to what the findings from Tromsø show or whether we see a more advanced (or possibly a less advanced) process. Furthermore, we study the possible distinction between the suffixed definite article (a declensional class marker) and the indefinite article and other free-standing forms that show gender agreement with the noun. Finally, we also explore the possible effect of semantic vs. morphophonological gender cues in the Trondheim dialect, as the results from Tromsø are relatively inconclusive on this aspect of the change.

We thus formulate the following research questions:

1. Is the Trondheim dialect also undergoing a change involving the loss of feminine gender, just like in Tromsø?

2. If so, is the rate of the change the same as in Tromsø, or do we see a more advanced (alternatively a less advanced) development?

3. Is there a distinction between indefinite articles ( $e i$ 'a.F', en 'a.M') and suffixed definite articles ( $-a$ and $-e n$ 'the'), attested in the Tromsø study (Rodina and Westergaard 2015a), as well as in previous studies on how gender is acquired and possibly lost across the lifespan ('attrition') (Rodina and Westergaard 2013a; Lohndal and Westergaard 2016)?

4. Are children and adults sensitive to semantic and/or morphophonological cues in gender acquisition?

\section{Methodology}

\subsection{Participants}

Altogether 71 child and adult native speakers of the Trondheim dialect participated in the study, divided into five age groups, as illustrated in Table 2. The child participants were born in Trondheim and grew up acquiring the local dialect. The adult participants were also born in the city and had lived there most of their lives. They were employees at the Norwegian University of Science and Technology, but did not have any background in linguistics.

\begin{tabular}{|l|l|l|l|}
\hline Group description & Number & Age range & Mean age \\
\hline Group 1: Pre-school children & 15 & $3 ; 4-5 ; 9$ & $4 ; 7$ \\
\hline $\begin{array}{l}\text { Group 2: Elementary school } \\
\text { children (grades 1 and 2) }\end{array}$ & 14 & $6 ; 1-7 ; 4$ & $6 ; 8$ \\
\hline $\begin{array}{l}\text { Group 3: Elementary school } \\
\text { children (grade 7) }\end{array}$ & 14 & $12 ; 1-13 ; 1$ & $12 ; 6$ \\
\hline Group 4: High school students & 15 & $18-19$ & 19 \\
\hline Group 5: Adults & 13 & $32-57$ & 44 \\
\hline
\end{tabular}

Table 2. Overview of the participant groups, specifying age in years;months for the children (Groups 1, 2 and 3) and years for the teenagers and adults (Groups 4 and 5).

\subsection{Materials and procedure}

The materials and procedure used in the study are similar to those developed in Rodina and Westergaard (2015a), except for a few adjustments. After a pilot test, a few nouns were replaced as they seemed unfamiliar to the children. We also adjusted some of the visual stimuli in order to provide a better match for the lexical items tested. An overview 
of the test items is provided in the Appendix. All participants took part in two production experiments. Both experiments elicited indefinite and double definite forms. The goal of Experiment 1 was to compare gender marking across the three classes of nouns (masculine, feminine and neuter). A total of 25 lexical items were distributed between the three genders: nine masculine, eight feminine, and eight neuter. ${ }^{7}$ Three masculine nouns (slange 'snake', kjole 'dress', bil 'car') and one neuter noun (eple 'apple') in the test are reported to be feminine in the Trondheim dialect, at least for some speakers. Three of these four nouns end in $-e$ and thus belong to the noun class that has undergone a change to the feminine in certain dialects, in analogy with the weak feminines. We nevertheless decided to include these nouns in Experiment 1 in order to keep the test as similar as possible to the Tromsø study. We report on the discrepancies in the results section.

The goal of Experiment 2 was to investigate gender marking on the four subclasses of feminines used in the Tromsø study. ${ }^{8}$ To recap for convenience, these are nouns denoting females with a zero ending, non-females ending in $-e$, nouns with both cues, and nouns with neither cue (cf. above for examples). The nouns were equally distributed between the four subclasses ( $6 \times 6 \times 6 \times 6)$. Additionally, four neuter nouns were used as fillers. No masculine nouns were included, in order to avoid priming. Before the experiment started, we presented the participants with three warm-up items to make sure that they had understood what to do.

The elicitation procedure used in both experiments is illustrated in (5) for a masculine noun. Note that the lead-in statement does not reveal the gender of the target noun. The phrases in (6) illustrate the corresponding responses expected for feminine and neuter nouns.

(5) (Pictures of a yellow and a red car shown simultaneously on the screen.)

Experimenter: $\quad$ Dette kaller vi bil. Kan du si hva vi har her?

'This we call car. Can you tell me what we see here?'

Expected response 1: En gul bil og en rød bil

a.Myellow car(M) and a.M red car( $M$ )

'A yellow car and a red car'

(The red car disappears - picture of a yellow car remains)

Experimenter: Hva forsvant?

'What disappeared?'

Expected response 2: Den røde bilen

the.M red car.DEF(M)

'The red car'

\footnotetext{
${ }^{7}$ The intention was to have eight nouns of each gender in the experiment, as in the Tromsø study, but by accident, one extra masculine noun was included.

${ }^{8}$ Although some rural dialects around Trondheim have apocope in the weak feminines (i.e., the final $-e$ is lost), the final $-e$ is retained in the Trondheim dialect, and this form was therefore used in the experiment, as in the Tromsø study (see above).
} 
a. Ei gul flaske og ei rød flaske. Den røde flaska a yellow bottle and a red bottle the red bottle

'A yellow bottle and a red bottle. The red bottle.'

b. Et gult tog og et rødt tog. Det røde toget a yellow train and a red train the red train

'A yellow train and a red train. The red train.'

The child participants were tested individually in daycare centers and schools, while the adults were tested at the university. The data were collected and transcribed by a researcher and a research assistant who are both native speakers of Norwegian. We counted responses with indefinite articles, prenominal determiners and suffixed definite articles separately. In both experiments the number of expected responses varied for different targets: The participants produced the indefinite articles twice and the double definite forms once per test item. In some cases, the target noun was missing in the response and only the indefinite article or prenominal determiner was used together with an attributive adjective, as shown in (7)-(8). Such responses are perfectly grammatical and were therefore included in the counts. We excluded responses where a different noun was used. There were several occurrences of self-corrections. In such cases we included the last variant produced by the speaker. In cases when a personal pronoun was used instead of the prenominal determiner den (e.g., hun dama 'she lady'), only the suffixed definite articles were included in the counts.

Et grønt hus og et gult.

a green house and a yellow

'A green house and a yellow one.'

Et grønt hus. Det grønne.

a green house - the green

'A green house. The green one.'

\section{Results}

\subsection{Experiment 1: Masculine-Feminine-Neuter}

Table 3 shows that the masculine indefinite article $e n$ and the neuter et are generally used appropriately with masculine and neuter nouns across all age groups. This is in sharp contrast to the feminine form $e i$, which is used infrequently, even by the adults. While the neuter is not fully in place in the youngest children, just like in the Tromsø study (Rodina and Westergaard 2015a: 12), the use of masculine en is target-like across all participant groups, except in the following cases: Occasional overgeneralization of feminine $e i$ is found with the nouns bil 'car', slange 'snake' and kjole 'dress' in Groups 1, 3, 4 and 5: altogether 16 occurrences in the data sample. No significant differences are found between the groups in the masculine (Oneway ANOVA, $\mathrm{F}_{4,66}=201, p>, 090$ ). In the neuter, overgeneralization of masculine en occurs mainly in the youngest age group (70\%), who are significantly different from the other participant groups $(p<, 001$ Group 1 vs. Groups 2-5). The use of feminine $e i$ with the neuter noun eple 'apple', which has been claimed to be feminine in the Trondheim dialect (cf. footnote above), occurs only twice in the data of Group 3. Nevertheless, many children seem to have particular problems with this noun, as about half of the children in Group 1 produce it with masculine gender (the indefinite article en). 
In the feminine, the highest rates for indefinite $e i$ are attested for Groups 4 and 5 (the teenagers and adults) $16 \%$ and 35\% respectively. However, it is virtually unattested in the child data, where it occurs as little as $4 \%, 0 \%$ and $11 \%$ in Groups $1-3$. Thus, all participant groups demonstrate a clear preference for masculine gender $e n$ with the feminines. For the production of $e i$ there is a statistically significant difference between the groups (Oneway ANOVA, $\mathrm{F}_{4,66}=3,57, p=, 011$ ), and a post-hoc Tukey HDS reveals that Group 5 differs significantly from Group $1(p=, 024)$ and Group 2 ( $p=$ ,009). Beyond that no significant differences are detected.

\begin{tabular}{|l|l|l|l|}
\hline Group & Masculine (en) & Feminine (ei) & Neuter (et) \\
\hline Group 1 & $96 \%$ & $4 \%$ & $70 \%$ \\
& $246 / 254$ & $9 / 219$ & $157 / 225$ \\
\hline Group 2 & $100 \%$ & $0 \%$ & $98 \%$ \\
& $247 / 247$ & $0 / 224$ & $219 / 224$ \\
\hline Group 3 & $99 \%$ & $11 \%$ & $98 \%$ \\
& $230 / 232$ & $24 / 208$ & $203 / 207$ \\
\hline Group 4 & $98 \%$ & $16 \%$ & $99 \%$ \\
& $264 / 268$ & $134 / 239$ & $236 / 238$ \\
\hline Group 5 & $99 \%$ & $35 \%$ & $100 \%$ \\
& $227 / 229$ & $70 / 200$ & $207 / 207$ \\
\hline
\end{tabular}

Table 3. Experiment 1: Gender marking on indefinite articles.

The speakers' individual preferences with the feminines are illustrated in Table 4. It is immediately clear that the majority of speakers (54/71) have a clear preference for the masculine en with the feminines, and use this form exclusively. This is the case especially among the children. Only two speakers (one in Group 4, one in Group 5) use the feminine ei exclusively, and the remaining 15 participants use both forms.

\begin{tabular}{|l|l|l|l|}
\hline Group & ei only & ei and en & en only \\
\hline Group 1 & $0 / 15$ & $1 / 15$ & $\mathbf{1 4 / 1 5}$ \\
\hline Group 2 & $0 / 14$ & $0 / 14$ & $\mathbf{1 4 / 1 4}$ \\
\hline Group 3 & $0 / 14$ & $3 / 14$ & $\mathbf{1 1 / 1 4}$ \\
\hline Group 4 & $1 / 15$ & $6 / 15$ & $\mathbf{8} / \mathbf{1 5}$ \\
\hline Group 5 & $1 / 13$ & $5 / 13$ & $\mathbf{7 / 1 3}$ \\
\hline
\end{tabular}

Table 4. Experiment 1: The use of the indefinite article ei (FEM) and en (MASC) with feminine nouns, $N$ participants/Total.

In double definite DPs, we considered gender agreement on the prenominal determiner (den vs. det for common vs. neuter) as well as the form of the declensional class marker on the definite suffix (-en, $-a$, and -et for masculine, feminine, and neuter). Table 5 shows that, as with the indefinite article, the youngest children (Group 1) still experience problems with the neuter, overgeneralizing common gender den and to some extent also the masculine suffix $-e n .^{9}$ At the same time target-like performance with neuter nouns is

\footnotetext{
${ }^{9}$ The neuter noun anker 'anchor' proved to be very difficult for the children in Group 1, and only two out of 15 children produced the double definite marking for this noun correctly. Also the neuter noun eple 'apple' was difficult for this group; four out of 20 responses used the definite suffix $-a$ with this noun, i.e.,
} 
observed for all other age groups, both with the determiner and the suffix. According to a Oneway ANOVA, the children in Group 1 are significantly different from the other participant groups both for the neuter determiner $\operatorname{det}\left(\mathrm{F}_{4,66}=14,8, p<, 001\right.$ for all groups) and the suffix -et $\left(\mathrm{F}_{4,66}=9,03, p \leq, 002\right.$ for all groups $)$.

Target-like performance is also observed for the prenominal determiner den with masculine and feminine nouns across all age groups. However, some deviations are found in the use of the definite suffixes $-e n$ and $-a$. In the masculine, the ending $-a$ occasionally appears with nouns that have been claimed to be feminine in Trondheim, bil 'car', slange 'snake', kjole 'dress', but also ovn 'oven' and stol 'chair' (41 cases in total). In the feminine, -en is used by all participant groups; the majority of the overgeneralizations occur in Group 1, which is significantly different both from Group 3 $(p=, 001)$ and Group $4(p=, 001)$ (Oneway ANOVA, $\left.\mathrm{F}_{4,65}=6,12, p<, 001\right)$.

\begin{tabular}{|l|l|l|l|l|l|l|}
\hline \multirow{2}{*}{ Group } & \multicolumn{3}{l|}{ Masculine } & Feminine & Neuter \\
\cline { 2 - 7 } & den & - en & den & $-\boldsymbol{a}$ & det & -et \\
\hline Group 1 & $99 \%$ & $93 \%$ & $97 \%$ & $77 \%$ & $63 \%$ & $79 \%$ \\
& $121 / 122$ & $105 / 113$ & $109 / 112$ & $78 / 102$ & $67 / 107$ & $85 / 107$ \\
\hline Group 2 & $100 \%$ & $90 \%$ & $100 \%$ & $89 \%$ & $99 \%$ & $100 \%$ \\
& $124 / 124$ & $111 / 123$ & $111 / 111$ & $98 / 110$ & $106 / 107$ & $111 / 111$ \\
\hline Group 3 & $100 \%$ & $91 \%$ & $100 \%$ & $99 \%$ & $100 \%$ & $100 \%$ \\
& $116 / 116$ & $106 / 116$ & $111 / 111$ & $111 / 112$ & $112 / 112$ & $112 / 112$ \\
\hline Group 4 & $100 \%$ & $93 \%$ & $100 \%$ & $97 \%$ & $99 \%$ & $99 \%$ \\
& $132 / 132$ & $118 / 127$ & $119 / 119$ & $116 / 119$ & $118 / 119$ & $113 / 114$ \\
\hline Group 5 & $100 \%$ & $98 \%$ & $100 \%$ & $87 \%$ & $100 \%$ & $100 \%$ \\
& $114 / 114$ & $114 / 116$ & $101 / 101$ & $85 / 98$ & $103 / 103$ & $101 / 101$ \\
\hline
\end{tabular}

Table 5. Experiment 1: Gender marking on double definite DPs, prenominal determiners and suffixes.

Table 6 illustrates the individual preferences for definite suffixes with feminines, showing that none of the informants consistently use the form that typically appears on masculines, -en. For the youngest children in Groups 1 and 2, half of them use - $a$ consistently, while the other half use the two forms interchangeably. We see a similar trend among the adults; eight out of 13 use $-a$ consistently, while five out of 13 use both suffixes. The children in Group 3 and the teenagers in Group 4 show a clear preference for the use of $-a$ with feminines (26/29). This means that most of the speakers display a gender system where the feminine indefinite article is replaced by the masculine form, while the definite suffix is stable, which corresponds to the system attested elsewhere, cf. section 2.2.

\begin{tabular}{|l|l|l|l|}
\hline Group & $-\boldsymbol{a}$ only & $-\boldsymbol{a}$ and - en & -en only \\
\hline Group 1 & $7 / 14^{10}$ & $7 / 14$ & 014 \\
\hline Group 2 & $7 / 14$ & $7 / 14$ & $0 / 14$ \\
\hline Group 3 & $13 / 14$ & $1 / 14$ & $0 / 14$ \\
\hline
\end{tabular}

the form that typically appears on feminine nouns. Other responses overgeneralized the ending typically used with masculine nouns, -en. See below for an account of these deviant responses.

${ }^{10}$ One of the informants in Group 1 does not produce definite suffixes on feminine nous in Experiment 1. In Experiment 2 this informant consistently produces the - $a$-ending on feminine nouns. 


\begin{tabular}{|l|l|l|l|}
\hline Group 4 & $13 / 15$ & $2 / 15$ & $0 / 15$ \\
\hline Group 5 & $8 / 13$ & $5 / 13$ & $0 / 13$ \\
\hline
\end{tabular}

Table 6. Experiment 1: The use of the definite suffixes $-a$ and -en with feminine nouns, $N$ participants /Total.

Figure 1 demonstrates frequencies of the use of - $a$ with the masculine nouns bil 'car', slange 'snake', kjole 'dress', ovn 'oven' and stol 'chair'. This use is characteristic of Groups 1, 2, 3 and 4 and occurs most frequently with the noun bil 'car' across all participant groups except for the youngest children.

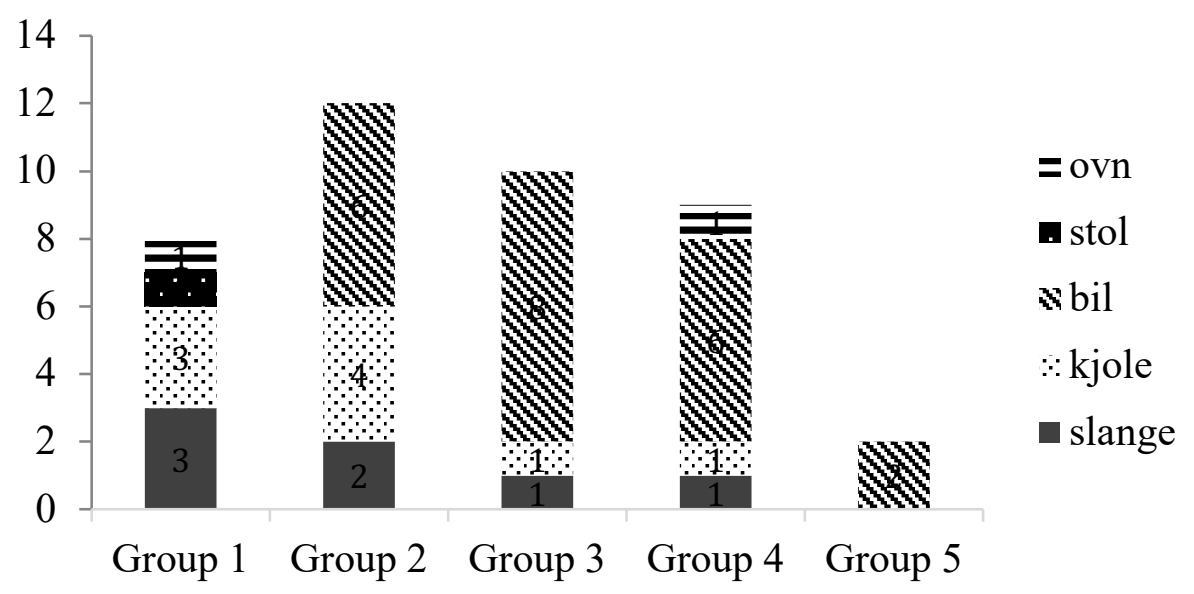

Fig. 1 Experiment 1: Use of the definite suffix - $a$ with the (masculine) nouns slange 'snake', kjole 'dress', bil 'car', stol 'chair' and ovn 'oven'

Figures 2 and 3 provide a comparison of gender marking in the feminine across the five age groups in Trondheim and Tromsø. The most striking difference is observed for the teenage and adult participants in Groups 4 and 5. In Trondheim the feminine indefinite article $e i$ is used considerably less frequently than in Tromsø: $16 \%$ vs. $56 \%$ in Group 4 and $35 \%$ vs. $99 \%$ in Group 5. Consequently, the contrast between the feminine indefinite article $e i$ and the suffixed definite article $-a$ is present for all participant groups in Trondheim, while in Tromsø it is evident only for Groups 1, 2, 3 and 4. The oldest participants in Tromsø use the feminine forms $e i$ and $-a$ consistently. The child participants behave rather similarly in both areas and show very low rates of feminine $e i$. Yet, the usage of the suffixed definite article $-a$ is noticeably lower in Groups 1, 2 and 5 in Trondheim than in Tromsø. It seems especially low for the preschoolers in Trondheim. No differences are observed for the prenominal determiner den in the two areas. 


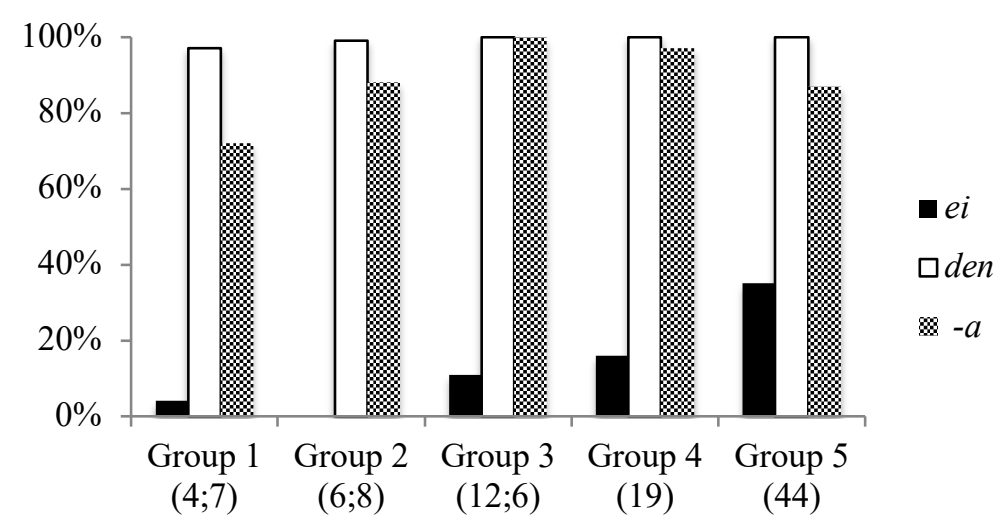

Fig. 2 Experiment 1, Trondheim: Gender marking in the feminine. Mean age for each group in brackets

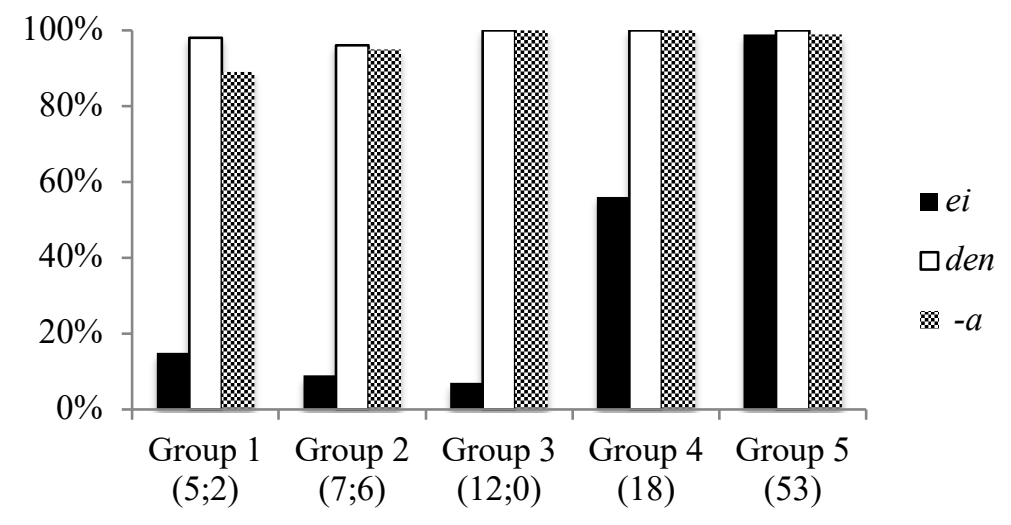

Fig. 3 Experiment 1, Tromsø: Gender marking in the feminine. Mean age for each group in brackets (Rodina and Westergaard 2015a: 168).

\subsection{Experiment 2: Feminine noun classes}

The results of Experiment 2 are presented in Table 6. As described above, in this experiment the same participants provide gender marking for four different classes of feminines, varying with respect to a semantic and a morphophonological cue (female referent and the ending $-e$ ). The usage pattern for the feminine indefinite article $e i$ is similar to the one observed in Experiment 1: It is used infrequently across all age groups, ranging between 6\% in the youngest children (Group 1) and 51\% in the adults (Group 5). A Oneway ANOVA reveals that between-group differences are significant across all four conditions: Female $-\mathrm{C}\left(\mathrm{F}_{4,66}=4,52, p=, 003\right)$, Female $-e\left(\mathrm{~F}_{4,66}=5,52, p=\right.$ $, 001)$, Non-female $-\mathrm{C}\left(\mathrm{F}_{4,66}=4,3, p=, 004\right)$ and Non-female $-e\left(\mathrm{~F}_{4,66}=3,2, p=, 018\right)$. Group 1 differs from Group 5 across all conditions, and from Group 4 in the Female -C and Female $-e$ conditions. Group 2 displays the same pattern as Group 1, except for the Female $-\mathrm{C}$ condition, where the difference is not significant $(p=, 058)$. No significant differences are detected for Group 3. It should be noted that the rates for the indefinite $e i$ are somewhat higher in Experiment 2 than in Experiment 1 across all age groups, possibly due to self-priming.

Table 6 also shows that the rates for feminine nouns denoting females (Female $-\mathrm{C}$ and Female $-e$ ) are somewhat higher than for nouns referring to non-female items (Nonfemale -C and Non-female -e). The results of Paired Samples t-tests reveal that semantics (Female $-\mathrm{C}$ and $-e$ vs. Non-female $-\mathrm{C}$ and $-e$ ) is a significant predictor only for 
Group $3(p=, 027)$ and Group $4(p=, 031)$. As in Tromsø, no significant differences are attested for the morhophonological cue.

\begin{tabular}{|l|l|l|l|l|l|}
\hline Group/Age & Female -C & Female $-\boldsymbol{e}$ & Non-female -C & Non-female $-\boldsymbol{e}$ & Neuter \\
\hline Group 1 & $7 \%$ & $7 \%$ & $6 \%$ & $6 \%$ & $89 \%$ \\
& $12 / 176$ & $12 / 149$ & $11 / 174$ & $10 / 176$ & $142 / 159$ \\
\hline Group 2 & $10 \%$ & $4 \%$ & $1 \%$ & $5 \%$ & $100 \%$ \\
& $17 / 168$ & $7 / 168$ & $2 / 168$ & $8 / 168$ & $168 / 168$ \\
\hline Group 3 & $37 \%$ & $32 \%$ & $20 \%$ & $21 \%$ & $97 \%$ \\
& $63 / 169$ & $55 / 169$ & $34 / 168$ & $35 / 167$ & $163 / 168$ \\
\hline Group 4 & $51 \%$ & $46 \%$ & $31 \%$ & $29 \%$ & $100 \%$ \\
& $91 / 178$ & $81 / 178$ & $55 / 179$ & $51 / 175$ & $180 / 180$ \\
\hline Group 5 & $51 \%$ & $51 \%$ & $49 \%$ & $45 \%$ & $100 \%$ \\
& $77 / 157$ & $79 / 156$ & $76 / 156$ & $68 / 150$ & $155 / 155$ \\
\hline
\end{tabular}

Table 6. Experiment 2: Gender marking on indefinite articles.

Tables 7 and 8 illustrate the individual production of indefinite articles with the feminines in Experiment 2. The majority of the participants in Groups 1 and 2 use only masculine en with feminine nouns. The children in Group 3 use only masculine en with Non-female nouns, but vary with the Female nouns. For Group 4, feminine ei seems to be used slightly more often with Female feminines, while en is used slightly more often with Non-female nouns. The semantic and morphophonological cues do not seem to affect the adult participants' choice of indefinite article at all.

\begin{tabular}{|l|l|l|l|l|l|l|}
\hline Group & \multicolumn{4}{|l|}{ Female -C } & Female $-\boldsymbol{l}$ \\
\hline & ei only & ei and en & en only & ei only & ei and en & en only \\
\hline Group 1 & $1 / 15$ & $0 / 15$ & $14 / 15$ & $0 / 15$ & $1 / 15$ & $14 / 15$ \\
\hline Group 2 & $0 / 14$ & $2 / 14$ & $12 / 14$ & $0 / 14$ & $1 / 14$ & $13 / 14$ \\
\hline Group 3 & $4 / 14$ & $5 / 14$ & $5 / 14$ & $3 / 14$ & $5 / 14$ & $6 / 14$ \\
\hline Group 4 & $4 / 15$ & $6 / 15$ & $5 / 15$ & $3 / 15$ & $7 / 15$ & $5 / 15$ \\
\hline Group 5 & $5 / 13$ & $5 / 13$ & $3 / 13$ & $4 / 13$ & $5 / 13$ & $4 / 13$ \\
\hline
\end{tabular}

Table 7. Experiment 2: The use of indefinite article ei (FEM) and en (MASC) with Female feminine nouns, $N$ participants/Total.

\begin{tabular}{|l|l|l|l|l|l|l|}
\hline Group & \multicolumn{2}{l|}{ Non-female -C } & \multicolumn{2}{l|}{ Non-female $\boldsymbol{e}$} \\
\hline & $\boldsymbol{e i \text { only }}$ & $\boldsymbol{e}$ i and $\boldsymbol{e n}$ & $\boldsymbol{e n}$ only & $\boldsymbol{e i}$ only & $\boldsymbol{e i}$ and $\boldsymbol{e n}$ & $\boldsymbol{e n}$ only \\
\hline Group 1 & $1 / 15$ & $0 / 15$ & $14 / 15$ & $0 / 15$ & $1 / 15$ & $14 / 15$ \\
\hline Group 2 & $0 / 14$ & $1 / 14$ & $13 / 14$ & $0 / 14$ & $2 / 14$ & $12 / 14$ \\
\hline Group 3 & $2 / 14$ & $1 / 14$ & $11 / 14$ & $2 / 14$ & $3 / 14$ & $9 / 14$ \\
\hline Group 4 & $1 / 15$ & $7 / 15$ & $7 / 15$ & $1 / 15$ & $7 / 15$ & $7 / 15$ \\
\hline Group 5 & $5 / 13$ & $5 / 13$ & $3 / 13$ & $4 / 13$ & $2 / 13$ & $7 / 13$ \\
\hline
\end{tabular}

Table 8. Experiment 2: The use of indefinite article ei (FEM) and en (MASC) with Nonfemale feminine nouns, $N$ participants/Total.

All the participants use the prenominal determiner den target-like (99\% or 100\%) with all feminines in Experiment 2. The use of neuter det is somewhat more error-prone for 
the youngest children $(83 \%, 71 / 86)$, which corresponds to the observation made in Experiment 1 (cf. Table 5).

The definite suffix $-a$ is used consistently with the feminines across all subclasses of nouns and all participant groups, except for the preschoolers in Group 1, who use this ending considerably less with one subclass of feminines, nouns denoting females and ending in a consonant (66\%). As in Experiment 1, there is some overgeneralization of the suffix -en with the feminines. According to a Oneway ANOVA, the between group differences are significant in the Female $-\mathrm{C}$ condition $\left(\mathrm{F}_{4,66}=5,99, p<, 001\right)$ and Female $-e$ condition $\left(\mathrm{F}_{4,66}=4,96, p=, 001\right)$. In the Female $-\mathrm{C}$ condition, the use of $-a$ by Group 1 differs significantly from all the other groups (Group $2(p=, 028)$, Group 3 ( $p=$ $, 001)$, Group $4(p=, 001)$ and Group $5(p=, 030))$. For the Female $-e$ condition, Group 1 differs from Group $3(p=, 004)$ and Group $4(p=, 008)$. The use of the suffix -et with the neuters is generally unproblematic.

\begin{tabular}{|l|l|l|l|l|l|}
\hline Group & Female -C & Female $-\boldsymbol{e}$ & Non-female -C & Non-female- $\boldsymbol{~}$ & Neuter \\
\cline { 2 - 6 } & $-\boldsymbol{a}$ & $-\boldsymbol{a}$ & $-\boldsymbol{a}$ & $-\boldsymbol{a}$ & $-\boldsymbol{e t}$ \\
\hline Group 1 & $66 \%$ & $81 \%$ & $81 \%$ & $83 \%$ & $95 \%$ \\
& $55 / 83$ & $63 / 78$ & $72 / 89$ & $72 / 87$ & $81 / 85$ \\
\hline Group 2 & $91 \%$ & $93 \%$ & $89 \%$ & $91 \%$ & $100 \%$ \\
& $73 / 80$ & $76 / 82$ & $74 / 83$ & $78 / 84$ & $82 / 82$ \\
\hline Group 3 & $97 \%$ & $99 \%$ & $100 \%$ & $100 \%$ & $100 \%$ \\
& $82 / 84$ & $82 / 83$ & $81 / 81$ & $82 / 82$ & $83 / 83$ \\
\hline Group 4 & $97 \%$ & $98 \%$ & $97 \%$ & $94 \%$ & $100 \%$ \\
& $86 / 89$ & $85 / 87$ & $87 / 90$ & $83 / 88$ & $87 / 87$ \\
\hline Group 5 & $88 \%$ & $82 \%$ & $93 \%$ & $93 \%$ & $100 \%$ \\
& $68 / 77$ & $63 / 77$ & $72 / 77$ & $68 / 73$ & $76 / 76$ \\
\hline
\end{tabular}

Table 9. Experiment 2: Suffixal forms in double definite DPs.

Tables 10 and 11 give results for the production of definite suffixes in Experiment 2 across groups and noun class. There is no consistent production of the ending -en (typically used for masculine nouns) for the feminines across speakers or individual nouns; that is, there is no speaker that consistently uses this ending, nor are there specific nouns that are generally produced with this form. For Non-female nouns there is a preference for the suffix - $a$ among all age groups. The majority of the participants in groups 2, 3 and 4 use $-a$ consistently also with feminines with female referents. The preschoolers in Group 1 differ in that the majority use both endings with the Female feminines. The majority of the adults (Group 5) use $-a$ only with Female nouns ending in a consonant, and for the Female $-e$ feminines, half of the participants use $-a$ consistently, while the other half use both forms interchangeably. Again, we see that most speakers display a system where the definite suffix is (relatively) stable, but the feminine indefinite article has been replaced by the masculine.

\begin{tabular}{|c|c|c|c|c|c|c|}
\hline Group & \multicolumn{3}{|c|}{ Female -C } & \multicolumn{3}{|c|}{ Female $-e$} \\
\hline & $-a$ only & $-a$ and $-e n$ & -en only & $-a$ only & $-a$ and -en & -en only \\
\hline Group 1 & $4 / 15$ & $10 / 15$ & $1 / 15$ & $4 / 15$ & $10 / 15$ & $1 / 15$ \\
\hline Group 2 & $12 / 14$ & $1 / 14$ & $1 / 14$ & $11 / 14$ & $3 / 14$ & $0 / 14$ \\
\hline Group 3 & $13 / 14$ & $1 / 14$ & $0 / 14$ & $12 / 14$ & $2 / 14$ & $0 / 14$ \\
\hline Group 4 & $14 / 15$ & $1 / 15$ & $0 / 15$ & $14 / 15$ & $1 / 15$ & $0 / 15$ \\
\hline Group 5 & $9 / 13$ & $4 / 13$ & $0 / 13$ & $6 / 13$ & $7 / 13$ & $0 / 13$ \\
\hline
\end{tabular}


Table 10. Experiment 2: The use of the definite suffix $-a$ and $-e n$ with Female feminine nouns, $N$ participants/Total.

\begin{tabular}{|l|l|l|l|l|l|l|}
\hline Group & \multicolumn{4}{|l|}{ Non-female -C } & \multicolumn{3}{l|}{ Non-female $\boldsymbol{e}$} \\
\hline & $-\boldsymbol{a}$ only & $-\boldsymbol{a}$ and $-\boldsymbol{e n}$ & $-\boldsymbol{e n}$ only & $-\boldsymbol{a}$ only & $-\boldsymbol{a}$ and $-\boldsymbol{e n}$ & $-\boldsymbol{e n}$ only \\
\hline Group 1 & $8 / 15$ & $6 / 15$ & $1 / 15$ & $10 / 15$ & $4 / 15$ & $1 / 15$ \\
\hline Group 2 & $11 / 14$ & $2 / 14$ & $2 / 14$ & $11 / 14$ & $2 / 14$ & $1 / 14$ \\
\hline Group 3 & $14 / 14$ & $0 / 15$ & $0 / 14$ & $14 / 14$ & $0 / 14$ & $0 / 14$ \\
\hline Group 4 & $14 / 15$ & $1 / 15$ & $0 / 15$ & $14 / 15$ & $1 / 15$ & $0 / 15$ \\
\hline Group 5 & $11 / 13$ & $2 / 13$ & $0 / 14$ & $11 / 13$ & $1 / 13$ & $1 / 13$ \\
\hline
\end{tabular}

Table 11: Experiment 2: The use of the definite suffix $-a$ and $-e n$ with Non-female feminine nouns, $N$ participants/Total.

Finally, figures 4-5 provide a comparison of the results across the four subclasses of feminines in Trondheim and Tromsø. At least two general observations can be made here. First, the Trondheim participants in Groups 1,2, 4 and 5 use ei considerably less with all subclasses of feminines than the Tromsø participants in the respective groups. The difference is especially pronounced for teenagers and adults (Groups 4 and 5). Group 3 constitutes an exception, since the scores for $e i$ are higher in the $7^{\text {th }}$ graders from Trondheim than in the corresponding Tromsø group. It should be noted that no such contrast was observed in Experiment 1. Secondly, participants' sensitivity to the semantic cue, found in both test areas, appears most pronounced in Groups 3 and 4, especially in the Trondheim area.

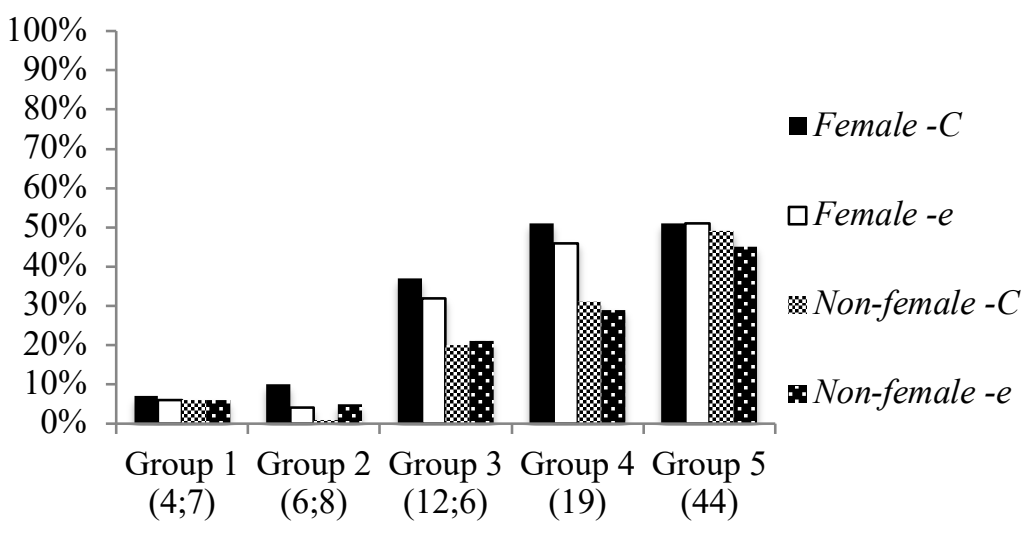

Fig. 4 Experiment 2, Trondheim: Gender marking on indefinite articles across three subclasses of feminines. Mean age for each group in brackets 


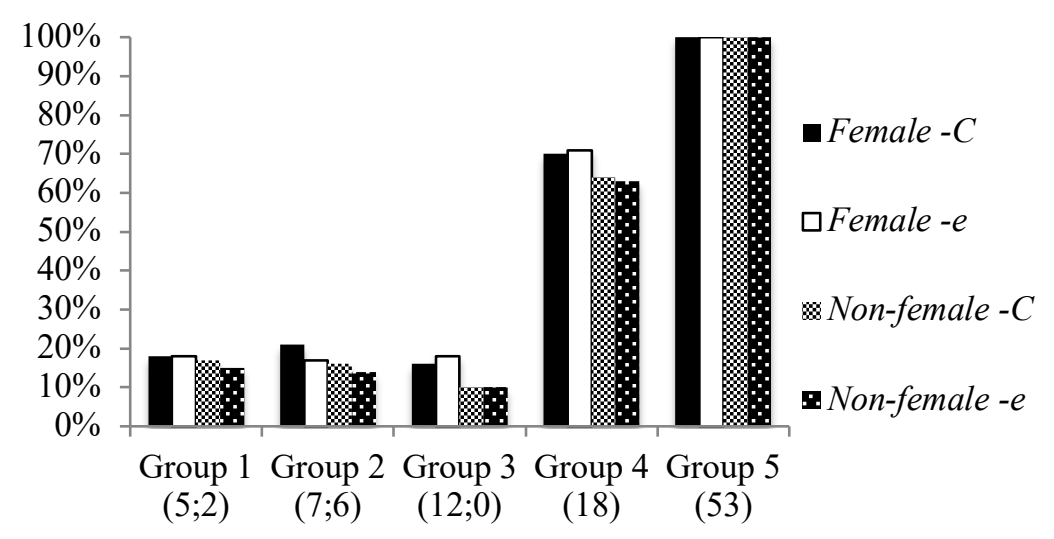

Fig. 5 Experiment 2, Tromsø: Gender marking on indefinite articles across three subclasses of feminines. Mean age for each group in brackets (Rodina and Westergaard 2015a: 173)

\section{Discussion}

In section 3, we introduced the following research questions:

1. Is the Trondheim dialect also undergoing a change involving the loss of feminine gender, just like in Tromsø?

2. If so, is the rate of the change the same as in Tromsø, or do we see a more advanced (alternatively a less advanced) development?

3. Is there a distinction between indefinite articles ( $e i$ 'a.F', $e n$ 'a.M') and suffixed definite articles ( $-a$ and $-e n$ 'the'), attested in the Tromsø study (Rodina and Westergaard 2015a), as well as in previous studies on how gender is acquired and possibly lost across the lifespan ('attrition') (Rodina and Westergaard 2013a; Lohndal and Westergaard 2016)?

4. Are children and adults sensitive to semantic and/or morphophonological cues in gender acquisition?

Focusing on the first question, we see that the results clearly demonstrate that the Trondheim dialect is also undergoing a change involving the loss of feminine gender. For the neuter, it is only in Group 1 that the subjects overgeneralize the masculine. This is consistent with the findings from Tromsø, where it was shown that neuter is not acquired until the age of approximately 7 (Rodina and Westergaard 2015a). For the feminine $e i$, there is a slow increase from hardly any occurrences in the youngest children to $35 \%$ in Group 5. The two youngest groups use virtually no feminine gender forms at all, and the one subject that produces the feminine indefinite article in Group 1 uses it alongside the masculine indefinite article.

Interestingly, the Trondheim results differ from the Tromsø results in Groups 4 and 5, in that the Trondheim groups use the feminine indefinite article considerably less than in Tromsø. For Group 4, the difference is $16 \%$ vs. $56 \%$ and for Group 5, 35\% vs. 99\% (cf. Experiment 1). One factor that may have contributed to this is that the adults in Group 5 are somewhat older in Tromsø with a median age of 53, while the median age in the Trondheim group is 44 . Nevertheless, our results suggest that the change is more advanced in Trondheim and has presumably started earlier. This tendency is also reflected in the individual results: In Tromsø as many as 23 out of 70 participants 
(32.9\%) used ei exclusively in (cf. above), but this was the case for only two out of 71 participants $(2.8 \%)$ in Trondheim (see Table 4$)$.

Assuming an analysis where the current change has started in the capital, Oslo, (setting aside the Bergen dialect, where the change was complete several hundred years ago), a likely explanation of this is that Trondheim is a larger city and also closer to Oslo. This would correspond to what we referred to above as city jumping, i.e., a phenomenon where the spread of a historical change in a specific feature of an urban vernacular may jump from one city to another (cf. Trudgill 1974, 1983; Taeldeman 2005; Vandekerckhove 2009). However, the difference between the oldest children in Tromsø and Trondheim (Groups 3), show the opposite, in that the Tromsø children in fact use feminine forms even less. This suggests that even though the change may have started earlier in Trondheim, it seems to be developing much faster in Tromsø, in that the slope of the development is much more abrupt.

In Rodina and Westergaard (2015a) it was argued that the major cause of the change was presumably a sociolinguistic one. Although our study has not been designed to test any sociolinguistic hypothesis, we would like to speculate a bit further, leaving a more detailed exploration for future work. It has been argued in Hårstad (2010), drawing on a wealth of literature, that a common feature of dialects spoken in major cities in Norway is that they gradually move towards a regional variety of Oslo speech. Trondheim has also been affected by this development, in that standard East Norwegian forms gain ground or intermediate forms appear that constitute a compromise between the traditional dialect and the standard form (see Kristoffersen 2016 for more discussion of intermediate forms from a phonetic perspective). Standard East Norwegian (at least the more prestigious varieties of this) could be said to be a spoken version of the written language Bokmål (cf. the discussion in section 2), and Dalen (1990) argues that the Trondheim dialect is also known to have been influenced by this written variety. Recall from section 2.1 that Bokmål allows the use of a two-gender system (common and neuter), and feminine forms are thus relatively infrequent in the written language. Historically Trondheim has also had a sociologically more prestigious variety (spoken by the 'higher' levels of society), which was argued to be essentially spoken Bokmål with the local intonation (Dalen 1978; Fintoft and Mjaavatn 1980; Stemshaug 1972), although the precise nature of this sociolect has proved hard to pin down. Hårstad (2010) finds that teenagers in Trondheim use forms that seem to be from this sociolect and also rate them higher than the traditional vernacular. However, he argues that this is due to influence from standard East Norwegian, not from this sociolect (Hårstad 2010: 337). Arguments involve the fact that teenagers view the sociolect as anachronistic and out of date, and that a range of phonetic and morphological changes in the dialect align with the Standard East Norwegian. For this reason, we do not believe that the existence of this sociolect has impacted our findings or that it explains them. Rather, Hårstad's (2010) extensive investigation supports influence from the standard language as a key component of why the change is happening. Our data cannot directly tell us when the change in the gender system started, and previous literature does not mention any such changes. In order to investigate that, older speaker groups would have to be investigated.

Concerning question 3 , we replicate the finding from Troms $\varnothing$ in that indefinite articles and suffixed definite forms are affected differently. However, as Table 5 demonstrates, there are some differences between the results from the two cities. There are a few suffixed definite forms in $-a$ that appear on masculine nouns in Trondheim. This involves a closed set of nouns; bil 'car', slange 'snake' and kjole 'dress'. As discussed in section 2, these are well-known exceptions in the Trondheim dialect, and as such, all they can tell us about the current change is that also these nouns (which have 
historically migrated to the feminine, in most cases due to the ending $-e$ ) are now developing back into masculine (or common) gender nouns. This may also explain the special problems the children have with the neuter noun eple 'apple' (cf. section 5.1): This has previously changed into a feminine noun in Trondheim, and now that the feminines are overgeneralized into masculine, this noun is also affected by the current development, accounting for the many cases of masculine gender used with this neuter noun. Thus, the children are presumably exposed to three different gender forms with this noun; neuter from the standard language (and most other dialects), feminine from the traditional Trondheim dialect, and masculine from other children who are treating this noun like any other feminine undergoing the change. Setting these special nouns aside, the Trondheim and Tromsø groups behave alike for masculine and neuter gender.

The interesting difference is to be found in the definite suffixes for feminine nouns. There appears to be an incipient change in the Trondheim gender system, whereby instead of the traditional - $a$ form, previously feminine nouns appear with the suffix -en, which is found on masculine nouns. This is more pronounced for Group 1 (only 77\% - $a$ forms in Experiment 1), but it also occurs to some extent in Group 5 (87\% - $a$ forms in Experiment 1). Investigating the data further, we find that there is considerable variation with respect to the definite suffix, and no subject is consistently using the -en form in both experiments. We interpret this difference between Trondheim and Tromsø as suggesting that the Trondheim change is somewhat more advanced than the Tromsø change, in that it has also started to affect the suffixed definite declension class markers.

In Rodina and Westergaard (2015a), it was argued that the definite suffixes are not affected by the ongoing change because they are acquired early - typically around the age of 2 (Anderssen 2006), while the indefinite articles are not in place until much later (around age 7, as mentioned above). This developmental pattern was used to argue that indefinite articles express gender whereas the sufficed articles are declension class markers that are not exponents of gender, contrary to what is claimed in much traditional work on Norwegian grammar (e.g. Faarlund, Lie and Vannebo 1997). The results from the Trondheim study indicate that the definite suffix may be affected after all, and this raises the gender vs. declension class discussion again with respect to the status of the definite article. In our view, our Trondheim results cannot be taken as straightforward evidence that the definite suffixes should be considered to be exponents of gender, as it seems clear that the two changes do not go hand in hand. That is, if the reason for the change is sociolinguistic and the direct cause is the high prestige of a spoken version of the written variety Bokmål, then it is not unlikely that the change in the declension class ending is a separate change in the same direction - towards a more standardized spoken variety, as argued by Hårstad (2010). Furthermore, the results from various other studies still hold (cf. references above), viz. that a change in the gender system does not (necessarily) affect the declensional system. That is to say, speakers do not seem to assign a gender feature on the definite suffix that needs to agree with the noun and true gender forms such as the indefinite article. For example, in dialects where the same change has occurred due to language contact, in certain areas in North Norway (cf. Conzett et al. 2011), the change has resulted in a stable two-gender system with no effects on the definite suffix. In order to investigate possible correlations between the loss of gender and changes in the declensional system, further research should track the development of this particular property of the change, both in Trondheim and elsewhere in Norway.

The last research question involves whether or not children and adults are sensitive to differences among cues for feminine gender assignment and thus different feminine noun classes. The results from the Tromsø study were inconclusive for this issue, as the 
differences attested were relatively small and could be related to individual (memorized) nouns rather than noun classes. Table 6 shows that the use of feminine gender forms for nouns denoting a female is somewhat higher than for nouns denoting a non-female, but this holds only for Groups 3 and 4, where the difference is statistically significant, and not for Group 5. In Group 2, there are more feminine gender forms used for nouns denoting a female and ending in a consonant, according to the group result. However, the results in Tables 10 and 11 show that this difference is due to intra-individual differences, and that there is no distinction stemming from semantic or morphophonological cues. Nor is there any difference for Group 1. Thus, there is no clear pattern across the Trondheim groups. A plausible explanation for nouns with a feminine referent being somewhat more robust and possibly resisting the change to some extent is that these nouns have distinct pronominal forms: A noun like dame 'woman' will be referred to by the pronoun ho 'she', whereas other feminine nouns (like flaske 'bottle') are referred to using den 'it' (cf. Westergaard and Rodina 2016 for the Tromsø dialect). Distinct pronominal forms reinforce the feminine cue for the learner, making it clearer that these nouns are feminine. Thus, the Trondheim results do not provide any clear evidence that semantic cues are any stronger than morphophonological ones in a situation of language change, which could have supported the semantic hierarchy of Corbett (1991). Our data thus correspond with findings from numerous acquisition studies, showing that children are typically less sensitive to semantic cues at an early stage (e.g., Gvozdev 1961; Kupisch et al. 2002; Rodina and Westergaard 2012). However, the morphophonological cue does not have any effect either, suggesting that the current change is affecting the whole feminine noun class more or less simultaneously.

\section{Summary and conclusion}

We have investigated the development of grammatical gender in Norwegian, where previous studies have shown that the three-gender system of the spoken language may be in the process of being reduced to a two-gender system in certain (urban) dialects. Two experiments have been carried out on five different age groups in Trondheim, and the results are compared to recent findings from Tromsø, where the loss of feminine gender has been attested in children and (to some extent) teenagers (Rodina and Westergaard 2015a). Our Trondheim data clearly show that the gender system is changing in this dialect too. The change is more advanced in Trondheim in that teenagers and adults use feminine gender (the indefinite article $e i$ ) considerably less than in the Tromsø dialect, although the development may be more gradual in Trondheim. The cause of the change is argued to be sociolinguistic, more specifically the high prestige of a spoken variety of the written standard Bokmål. In the Tromsø study, the definite suffixed article remains unaffected by the gender change, and Rodina and Westergaard (2015a) have argued that this is evidence that the definite suffix is not an exponent of gender in Norwegian, which is in accordance with standard definitions of gender (cf. Hockett 1958), but contra traditional grammars such as Faarlund, Lie and Vannebo (1997). Somewhat surprisingly, we see an indication that there is a change affecting the declension class system in the Trondheim data, in that there is some use of the masculine definite suffix -en attested with (previously) feminine nouns in the youngest speakers. However, we speculate that this is an independent development in the same direction and not a direct result of the change in the gender system, as the two changes do not go hand in hand. Finally, we have investigated the possible effect of a 
semantic and a morphophonological cue, concluding that neither has a crucial effect on the change and that the loss of feminine gender seems to affect the whole class of feminine nouns simultaneously. 
Appendix A. List of stimuli in Experiment 1

\begin{tabular}{|l|l|l|}
\hline Masculine & Feminine & Neuter \\
\hline bil 'car' & bru 'bridge' & tog 'train' \\
\hline frosk 'frog' & kake 'cake' & hus 'house' \\
\hline kopp 'cup' & bøtte 'bucket' & glass 'glass' \\
\hline slange 'snake' & såpe 'soap' & anker 'anchor' \\
\hline stol 'chair' & jakke 'jacket' & eple 'apple' \\
\hline ring 'ring' & høne 'hen' & ratt 'steering wheel' \\
\hline kjole 'dress' & gås 'goose' & skip 'ship' \\
\hline ovn 'oven' & trampoline 'trampoline' & bein 'bone' \\
\hline traktor 'tractor' & & \\
\hline
\end{tabular}

Appendix B. List of stimuli in Experiment 2

\begin{tabular}{|l|l|l|l|l|}
\hline Female -C & Female -e & Non-female -C & Non-female -e & Neuter \\
\hline $\begin{array}{l}\text { dronning } \\
\text { 'queen' }\end{array}$ & $\begin{array}{l}\text { dame } \\
\text { 'lady' }\end{array}$ & $\begin{array}{l}\text { bok } \\
\text { 'book' }\end{array}$ & $\begin{array}{l}\text { flaske } \\
\text { 'bottle' }\end{array}$ & $\begin{array}{l}\text { fjes } \\
\text { 'face' }\end{array}$ \\
\hline $\begin{array}{l}\text { datter } \\
\text { 'daughter' }\end{array}$ & $\begin{array}{l}\text { prinsesse } \\
\text { 'princess' }\end{array}$ & $\begin{array}{l}\text { seng } \\
\text { 'bed' }\end{array}$ & $\begin{array}{l}\text { krone } \\
\text { 'crown' }\end{array}$ & $\begin{array}{l}\text { fly } \\
\text { 'plane' }\end{array}$ \\
\hline $\begin{array}{l}\text { søster } \\
\text { 'sister' }\end{array}$ & $\begin{array}{l}\text { kvinne } \\
\text { 'woman' }\end{array}$ & $\begin{array}{l}\text { mus } \\
\text { 'mouse' }\end{array}$ & $\begin{array}{l}\text { stjerne } \\
\text { 'star' }\end{array}$ & $\begin{array}{l}\text { monster } \\
\text { 'monster' }\end{array}$ \\
\hline $\begin{array}{l}\text { kjerring } \\
\text { 'old lady' }\end{array}$ & $\begin{array}{l}\text { jente } \\
\text { 'girl' }\end{array}$ & $\begin{array}{l}\text { and } \\
\text { 'duck' }\end{array}$ & $\begin{array}{l}\text { såpe } \\
\text { 'soap' }\end{array}$ & $\begin{array}{l}\text { troll } \\
\text { 'troll' }\end{array}$ \\
\hline $\begin{array}{l}\text { heks } \\
\text { 'witch' }\end{array}$ & $\begin{array}{l}\text { dukke } \\
\text { 'doll' }\end{array}$ & $\begin{array}{l}\text { vogn } \\
\text { 'pram' }\end{array}$ & $\begin{array}{l}\text { lampe } \\
\text { 'lamp' }\end{array}$ & \\
\hline $\begin{array}{l}\text { bestemor } \\
\text { 'grandmother' }\end{array}$ & $\begin{array}{l}\text { kone } \\
\text { 'wife' }\end{array}$ & $\begin{array}{l}\text { dør } \\
\text { 'door' }\end{array}$ & $\begin{array}{l}\text { bøtte } \\
\text { 'bucket' }\end{array}$ & \\
\hline
\end{tabular}

\section{References}

Anderssen, Merete. 2006. The Acquisition of Compositional Definiteness. PhD dissertation, University of Tromsø.

Alsos, Kjersti. 2016. Genus i tromsødialekten: En komparativ undersøkelse av genussystemet fra to ulike områder $i$ Tromsø - $i$ et sosiolingvistisk perspektiv ['Gender in the Tromsø dialect: A comparative study of the gender system in two different areas of Troms $\varnothing-$ in a sociolinguistic perspective']. Master thesis, UIT The Arctic University of Norway.

Beito, Olav T. 1954. Genusskifte i nynorsk ['Gender change in nynorsk']. Oslo: Det Norske Videnskaps-Akademi.

Conzett, Philipp, Åse Mette Johansen, and Hilde Sollid. 2011. Genus og substantivbøying i nordnorske språkkontaktområder. ['Gender and noun declension in North Norwegian contact areas'] Nordand Tidsskrift for Andrespråksforskning 6: 35-71.

Corbett, Greville G. 1991. Gender. Cambridge: Cambridge University Press.

Dalen, Arnold. 1978. Trondheimsmålet. ['The Trondheim dialect'] Trondheim: Nidaros Mållag.

Dalen, Arnold. 1990. Talemålet i Trondheim. ['The spoken dialect in Trondheim'.] In Den store dialektboka, ed. Ernst Håkon Jahr, 205-209. Oslo: Novus.

Enger, Hans-Olav. 2004. On the relation between gender and declension: A diachronic perspective from Norwegian. Studies in Language 28:1, 51-82.

Faarlund, Jan Terje, Svein Lie, and Kjell Ivar Vannebo. 1997. Norsk referansegrammatikk ['A Reference Grammar of Norwegian']. Oslo: Universitetsforlaget.

Fintoft, Knut and Per Egil Mjaavatn. 1980. Språksosiologiske forhold i Trondheim bymål.

['Sociolinguistics aspects of the Trondheim dialect'.] Trondheim: Tapir.

Gvozdev, Aleksandr Nikolaevič. 1961. Formirovanie u rebenka grammatičeskogo stroja 
Russkogo jazyka. ['Language development of a Russian child'.] Moscow: APN RSFSR. Haugen, Einar. 1966. Language Conflict and Language Planning: The Case of Modern Norwegian. Cambridge, MA: Harvard University Press.

Haugen, Einar. 1976. The Scandinavian Languages: An Introduction to Their History. London: Faber.

Hockett, Charles F. 1958. A Course in Modern Linguistics. New York: MacMillan.

Hoel, Ivar. 1915. Kristiansundsmålet. Maal og minne. 1-63.

Hårstad, Stian. 2010. Unge språkbrukere i gammel by: En sosiolingvistisk studie av ungdoms talemål $i$ Trondheim ['Young language users in an old city: A sociolinguistic study of adolescents' speech in Trondheim']. PhD dissertation, Norwegian University of Science and Technology.

Jahr, Ernst Håkon. 1998. Sociolinguistics in historical language contact: The Scandinavian languages and Low German during the Hanseatic period. In Language change: Advances in historical sociolinguistics, ed. Ernst Håkon Jahr, 119-139. Berlin: Mouton de Gruyter.

Jahr, Ernst Håkon. 2001. Historical sociolinguistics: The role of Low German language contact in the Scandinavian typological split of the late Middle Ages. Lingua Posnaniensis 43: 95104.

Johannessen, Janne Bondi, Joel Priestley, Kristin Hagen, Tor A. Åfarli, and Øystein A. Vangsnes 2009. The Nordic Dialect Corpus - an Advanced Research Tool. In Proceedings of the 17th Nordic Conference of Computational Linguistics NODALIDA 2009, Vol. 4, eds. Kristiina Jokinen and Eckhard Bick. [NEALT Proceedings Series 4], 73-80. Tartu: Tartu University.

Kristoffersen, Gjert. 2016. Apikal istedenfor palatal/n/ og /1/ i nordnorsk: En kompromissform? ['Apical instead of palatal /n/ and /1/ in North Norwegian: A compromise form?'] In Helt fabelaktig! Festskrift til Hanne Gram Simonsen på 70-årsdagen, ed. Hans-Olav Enger, Monica I. Norvik Knoph, Kristian E. Kristoffersen, and Marianne Lind, 81-95. Oslo: Novus.

Kupisch, Tanja, Natascha Müller, and Katja Cantone. 2002. Gender in monolingual and bilingual first language acquisition: Comparing Italian and French. Lingue e Linguaggio $1: 107-147$ : SEPE:

Lohndal, Terje and Marit Westergaard. 2016. Grammatical Gender in American Norwegian Heritage Language: Stability or attrition? Frontiers in Psychology 7:344. doi: 10.3389/fpsyg.2016.00344.

Lundquist, Björn, Yulia Rodina, Irina Sekerina, and Marit Westergaard. 2016. Gender change in Norwegian dialects: Comprehension precedes production. Linguistics Vanguard 2:1, 69-83. doi: 10.1515/lingvan-2016-0026.

Lødrup, Helge. 2011. Hvor mange genus er det i Oslo-dialekten? ['How many genders does the Oslo dialect have?'] Maal og Minne 2: 120-136.

Norsk ordbok, ed. Hellevik, Alf. Oslo: Det norske Samlaget (1966).

Rodina, Yulia and Marit Westergaard. 2012. A cue-based approach to the acquisition of grammatical gender in Russian. Journal of Child Language 39(5): 1077-1106.

Rodina, Yulia and Marit Westergaard. 2013a. The acquisition of gender and declension in a nontransparent system: monolinguals and bilinguals. Studia Linguistica 67(1): 47-67.

Rodina, Yulia and Marit Westergaard. 2013b. Two gender systems in one mind: The acquisition of grammatical gender in Russian-Norwegian bilinguals. In Hamburg Studies on Linguistic Diversity 1 ['Multilingualism and Language Diversity in Urban Areas: Acquisition, identities, space, education'], 95-126. Amsterdam: John Benjamins.

Rodina, Yulia and Marit Westergaard. 2015a. Grammatical gender in Norwegian: Language acquisition and language change. Journal of Germanic Linguistics 27(2): 145-187.

Rodina, Yulia and Marit Westergaard. 2017. Grammatical gender in bilingual NorwegianRussian acquisition: The role of input and transparency. Bilingualism: Language and Cognition 20(1): 197-214.

Røyneland, Unn. 2005. Dialektnivellering, ungdom og identitet. Ein komparativ studie av språkleg variasjon og endring i to tilgrensande dialektområde, Røros og Tynset. ['Dialect leveling, youth and identity. A comparative study in language variation and change in two 
neighboring dialect areas, Røros and Tynset.'] Doctoral dissertation, University of Oslo.

Røyneland, Unn. 2009. Dialects in Norway: catching up with the rest of Europe? International Journal of the Sociology of Language 196/197: 7-30.

Stabell, Kristine M. 2016. "Vi sir aldri ei". En studie av femininum i altadialekten ["'We never say ei": A study of feminine gender in the Alta dialect']. Master thesis, University of Stavanger.

Stausland Johnsen, Sverre. 2015. Dialect change in South-East Norway and the role of attitude in diffusion. Journal of Sociolinguistics 19. 612-642.

Stemshaug, Ola. 1972. Sosiolingvistiske forhold i Trøndelag ['Sociolinguistics relations in Trøndelag']. In Trøndermål. Språkarv og språkforhold i Trøndelag og på Nordmøre, ed. Arnold Dalen and Ola Stemshaug, 48-66. Oslo: Det Norske Samlaget.

Taeldeman, Johan. 2005. The influence of urban centres on the spatial diffusion of dialect phenomena. In Dialect Change: Convergence and Divergence in European Languages, ed. Peter Auer, Frans Hinskens, and Paul Kerswill, 263-284. Cambridge: Cambridge University Press.

Torp, Arne. 2005. The Nordic Languages in the 19th Century. Nordic Languages. An International Handbook of the History of the North Germanic Languages, Vol. 2, ed. Oscar Bandle, Kurt Braunmüller, and Ernst Håkon Jahr, 1425-1436. Berlin: Walter de Gruyter.

Trosterud, Trond. 2001. Genustilordning i norsk er regelstyrt. Norsk Lingvistisk Tidsskrift 19: $29-57$.

Trudgill, Peter. 1974. Linguistic change and diffusion: Description and explanation in sociolinguistic geography. Language in Society 1: 179-195.

Trudgill, Peter. 1983. On Dialect: Social and Geographical Perspectives. Oxford: Blackwell.

Trudgill, Peter. 2013. Gender maintenance and loss in Totenmålet, English, and other major Germanic varieties. In In search of Universal Grammar: From Old Norse to Zoque, ed. Terje Lohndal, 77-107. Amsterdam: John Benjamins.

Vagstein, Anne. 2009. Hvor mange genus har norsk? En diskusjon av genusinndelingskriterier. ['How many genders does Norwegian have? A discussion of criteria for gender categorization.'] Master thesis, University of Oslo.

Vandekerckhove, Reinhild. 2009. Urban and rural language. In Language and Space: An International Handbook of Linguistic Variation, ed. Peter Auer and Jürgen Erich Smith, 315-332. Berlin: Mouton de Gruyter.

Venås, Kjell. 1993. On the choice between two written standards in Norway. In Language Conflict and Language Planning, ed. Ernst Håkon Jahr, 263-278. Berlin/New York: Mouton de Gruyter.

Vikør, Lars S. 1995. The Nordic Languages: Their Status and Interrelations. Oslo: Novus Press. Westergaard, Marit and Yulia Rodina. 2016. Hvor mange genus er det i Tromsødialekten? ['How many genders does the Tromsø dialect have?'] Maal and Minne 2: 159-189.

Westergaard, Marit (in press). Language Acquisition, Microcues, Parameters, and Morphosyntactic Change. In Richard D. Janda, Brian D. Joseph and Barbara S. Vance (eds.), Handbook of Historical Linguistics, Volume 2. Wiley/Blackwell Publishers. 